\title{
Refined mapping of the gene encoding the p127 kDa UV-damaged DNA-binding protein (DDB1) within 11q12-q13.1 and its exclusion in Best's vitelliform macular dystrophy
}

\author{
H eidi Stöhr ${ }^{1}$, A ndreas M arquardt ${ }^{1}$, A ndrea R ivera ${ }^{1}$, U Irich Kellner $^{2}$ and \\ Bernhard HF Weber ${ }^{1}$ \\ ${ }^{1}$ Institut für H umangenetik, B iozentrum, U niversität Würzburg, 97074 W ürzburg, G ermany \\ ${ }^{2}$ U niversität-K linikum B enjamin Franklin, Freie U niversität B erlin, 12200 B erlin, G ermany
}

\begin{abstract}
Best's vitelliform macular dystrophy (Best's disease) is an autosomal dominant disorder of unknown causes and is typically characterised by an accumulation of lipofuscin-like material in the subretinal space of the macula. The disease gene has been localised to chromosome 11q12-13.1 within a $1.4 \mathrm{Mbp}$ interval flanked by markers at D11S1765 and uteroglobin (UGB). Here we report the refined mapping of the gene encoding the p127 kDa subunit (DDB1) of a UV damage-specific DNA binding protein within the D11S1765-UGB region. Northern blot analysis demonstrates an abundant expression of the DDB1 transcript in the retina suggesting a functional role for DDB1 in this tissue. These considerations together with the chromosomal localisation have led us to evaluate the possible involvement of DDB1 in the pathogenesis of Best's disease.
\end{abstract}

Keywords: Macular degeneration; Best's vitelliform macular dystrophy; chromosome 11; UV-damaged DNA-binding protein; candidate gene approach

\section{Introduction}

Best's vitelliform macular dystrophy (Best's disease; O M IM 153700) is an autosomal dominant disorder that appears to be both clinically and genetically homogenous. ${ }^{1-3}$ D uring the life of one patient there is progression of the disorder from the subclinical (reduced

Correspondence: Bernhard HF Weber, Institut für H umangenetik, Biozentrum, A m Hubland, D-97074 Würzburg, Germany. Tel: +49 931888 4062; Fax: +49 931888 4069; E-mail: bweb@biozentrum.uni-wuerzburg.de

R eceived 100 ctober 1997; revised 8 January 1998; accepted 16 January 1998 electro-oculogram, E O G), to the clinical (typical vitelliform lesion in the macular area) and, finally, to the atrophic stage. ${ }^{4,5}$ The underlying biochemical defect in Best's disease is still unknown.

A $s$ an initial step towards the identification of the Best's disease gene, its locus was mapped to chromosome 11 by genetic linkage analysis ${ }^{2,3}$ and was subsequently refined to a 1-2 cM interval in 11q12-13.1 flanked by loci D $11 S 1765$ and uteroglobin (U G B). ${ }^{6,7}$ $M$ ore recently, a high coverage P1-derived artificial chromosome (PAC) contig encompassing the entire B est's disease locus was constructed ${ }^{8}$ greatly facilitating further gene cloning efforts. 
By fluorescent in situ hybridisation the gene encoding the p127 subunit (DDB1) of a heterodimeric damage-specific DNA binding protein, $D D B$, was previously assigned to chromosome $11 q 12-q 13 .^{9}$ As part of our effort to construct a comprehensive gene map of the Best's disease region we have now mapped the gene within the minimal candidate interval and have determined its expression profile with particular emphasis on retina and retinal pigment epithelium, those tissues which are of primary interest in the pathogenesis of Best's disease. Moreover, we have analysed the entire coding region of the gene in six $B$ est's disease patients unrelated by genealogy.

\section{Materials and Methods}

\section{Physical Mapping of the DDB1 Transcript and Northern Blot Analysis}

The construction and assembly of the PA C clone contig used to refine the localisation of the D DB 1 gene has been reported elsewhere. ${ }^{8}$ Primers $3^{\prime} F$ and $3^{\prime} R$ (Table 1 ) and overlapping PA C s dJ 398K 24, dJ 71C 4 and dJ 506K 16 were used to amplify a $287 \mathrm{bp}$ fragment derived from the $3^{\prime}-U T R$ of the DDB 1 gene (Figure $1 a, b, c$ ), whilst the location of the 5 '-end of the gene was identified by PCR amplification of a 62 bp fragment using primers D 1 and D 2 (Figure $1 C$ ).
For N orthern blot analysis, total R NA $(12 \mu \mathrm{g})$ isolated from frozen lung, cerebellum, RPE and retinal tissue and the R PE cell line, ARPE-19 10 was electrophoretically separated in $1.2 \%$ agarose gels containing $0.6 \mathrm{~m}$ formaldehyde and vacuum-blotted onto nylon membrane. The filter was hybridised with radiolabelled DDB 1 cDNA fragment 6 (Table 1, Figure $1 \mathrm{c}$ ) or a human $\beta$-actin $\mathrm{CDNA}$ probe at $65^{\circ} \mathrm{C}$. The final wash was in $0.2 \times \mathrm{SSC} / 0.1 \% \mathrm{SDS}$ at $65^{\circ} \mathrm{C}$.

\section{Patients and Families}

D iagnosis of patients affected with B est's disease was based on mode of inheritance, funduscopic abnormalities and reduced EOGs. Of six unrelated German patients with a known family history of the disease, we were able to recruit additional affected and unaffected family members in three cases, namely in families $\mathrm{R}, \mathrm{H}$ and $\mathrm{W}$, for pedigree analysis. $\mathrm{M}$ icrosatellite markers were selected based on their close vicinity to the Best's disease gene $e^{7,11,12}$ and included D 11S1765, D 11S4076 and U G B. H aplotypes were established under the assumption that possible recombination events would be minimised.

\section{SSCA and Sequencing Analysis}

For single-stranded conformational analysis (SSCA) and sequencing, total RNA was either prepared from E pstein $B$ arr virus (EBV) transformed lymphocytes derived from affected patients or from peripheral blood lymphocytes using the RNA-Clean-LS system (A ngewandte Gentechnologie Systeme). R NA s were reverse transcribed using the SU PER SCRIPT preamplification system ( $\mathrm{ibco}, \mathrm{BR} L)$ ). The resulting

Table 1 Oligonucleotide primers used for D D B 1 analysis

\begin{tabular}{|c|c|c|c|c|c|c|}
\hline Fragment & $\begin{array}{l}\text { Primer } \\
\text { name }\end{array}$ & $\begin{array}{l}\text { Primer sequence } \\
5^{\circ} \rightarrow 3^{\circ}\end{array}$ & $\begin{array}{l}\text { A nnealing } \\
\text { temp. } \\
\left({ }^{\circ} \mathrm{C}\right)\end{array}$ & $\begin{array}{l}\mathrm{MgCl}_{2} \\
(\mathrm{mM})\end{array}$ & $\begin{array}{l}\text { Restriction } \\
\text { enzyme }\end{array}$ & $\begin{array}{l}\text { Fragment } \\
\text { sizes } \\
\text { (bp) }\end{array}$ \\
\hline- & $\begin{array}{l}\text { DF } \\
\text { DR }\end{array}$ & $\begin{array}{l}\text { (-74)C CA CCTG TCTTTTCG CTT G (-56) } \\
(+3459) \text { TT G G G G A G G TCA G A A A G }(+3441)\end{array}$ & 55 & 1.0 & - & 3533 \\
\hline 1 & $\begin{array}{l}\text { DF } \\
\text { D } 1\end{array}$ & $\begin{array}{l}(-74) \text { C CA CCTG TCTTTTCG CTTG }(-56) \\
(+502) \text { T GACATCA ATGACATGCA G }(+483)\end{array}$ & 56 & 1.0 & Avall & $\begin{array}{l}296 \\
175 \text { and } 105\end{array}$ \\
\hline 2 & $\begin{array}{l}\text { D } 2 \\
\text { D } 4\end{array}$ & $\begin{array}{l}(+441) \text { C G A TA A TA A A G A A CTCA A G G C }(+461) \\
(+967) \text { A CA CA A CA C CA TTA TCA A G G }(+948)\end{array}$ & 54 & 1.0 & $\mathrm{Ncol}$ & $\begin{array}{l}317 \\
210\end{array}$ \\
\hline 3 & $\begin{array}{l}\text { D } 3 \\
\text { D } 6\end{array}$ & $\begin{array}{l}\text { (+925)T CTA TT G CT G A G T G CTT G A C (+944) } \\
(+1438) \text { A G A CCA A CCTCA C C GA T G C }(+1420)\end{array}$ & 56 & 1.5 & Pvull & $\begin{array}{l}316 \\
198\end{array}$ \\
\hline 4 & $\begin{array}{l}\text { D } 5 \\
\text { D } 8\end{array}$ & $\begin{array}{l}(+1399) \text { CA G CTTA TCCA GA TCA CTTC }(+1418) \\
(+2020) \text { T G A G GTTG A CA TTT G A G A A }(+2001)\end{array}$ & 54 & 1.0 & Pstl/H hal & $\begin{array}{l}271 \\
190 \text { and } 161\end{array}$ \\
\hline 5 & $\begin{array}{l}\text { D } 7 \\
\text { D } 10\end{array}$ & $\begin{array}{l}(+1955) \text { G TTCT G A C CG CCCCA CT G }(+1972) \\
(+2598) \text { CA CTTCCTTTTCA G CCA CA G (+2579) }\end{array}$ & 59 & 1.5 & Hhal & $\begin{array}{l}332 \\
190 \text { and } 122\end{array}$ \\
\hline 6 & $\begin{array}{l}\text { D } 9 \\
\text { D } 12\end{array}$ & $\begin{array}{l}(+2548) \text { G TCTTTCA G TA TTC G G A TG G }(+2568) \\
(+3159) \text { G TCCA G CA G G A G G TTG TA C }(+3141)\end{array}$ & 56 & 1.5 & X hol & $\begin{array}{l}322 \\
290\end{array}$ \\
\hline 7 & $\begin{array}{l}\text { D } 11 \\
\text { DR }\end{array}$ & $\begin{array}{l}\text { (+3105)CA TGATA G G G CT G G T G A CC }(+3123) \\
(+3459) \text { TT G G G G A G G G TCA G A A G G }(+3441)\end{array}$ & 59 & 1.5 & BstNI & $\begin{array}{l}188 \\
167\end{array}$ \\
\hline $3^{\prime} U T R$ & $\begin{array}{l}3^{\prime} F \\
3^{\prime} R\end{array}$ & $\begin{array}{l}(+3780) \text { T G TA TCT CA CA CT CA T G C }(+3797) \\
(+4067) \text { CTA A CA A TTCA CA TCCTC }(+4050)\end{array}$ & 56 & 1.5 & - & 287 \\
\hline
\end{tabular}


CDNA s served as a template for subsequent PCR reactions. Oligonucleotide primers were designed from the full length CD NA sequence of the published D D B 1 gene ( $G$ enB ank $A$ CC. No. U 18299; Table 1). DDB 1 cDNA containing the entire coding sequence was amplified using primer pair D F/D R. For SSCA, nested primers were used to amplify seven overlapping CDNA fragments (Figure 1c) by adding $0.1 \mu \mathrm{l}$ $\left[\alpha{ }^{32} \mathrm{P}\right]-d C T P(3000 \mathrm{Ci} / \mathrm{mmol})$ followed by incubation of a $5 \mu \mathrm{l}$ aliquot with selected restriction enzymes ( $G i b c o, B R L)$ to obtain appropriate fragment sizes (Table 1). Digested PCR products were mixed 1:1 with stop buffer (95\% formamide, $5 \mathrm{mM} \mathrm{NaOH}, 0.1 \%$ bromo-phenolblue, $0.1 \%$ xylene cyanol). Prior to loading on $6 \%$ non-denaturing polyacrylamide gels with and without $5 \%$ glycerol, samples were heated at $80^{\circ} \mathrm{C}$ for $5 \mathrm{~min}$. A fter electrophoresis at $35 \mathrm{~W}$ for $4-9 \mathrm{~h}$ at $4^{\circ} \mathrm{C}$, gels were dried and exposed for $12-48 \mathrm{~h}$ for autoradiography. Sequencing of forward and reverse strands of fragments 1,2 , 6 and 7 (Figure 1c) were carried out using the Thermo Sequenase radiolabelled terminator cycle sequencing kit (A mersham).

\section{Results}

Physical Mapping of DDB1

U sing oligonucleotide primers $3^{\prime} F$ and $3^{\prime} R$ a $287 \mathrm{bp}$ fragment corresponding to the 3 '-untranslated region (UTR) of the human D D B 1 gene was specifically PCR amplified in PAC DNA dJ $398 \mathrm{~K} 24$, dJ $71 C 4$ (Figure la,b). This positions the DDB1 gene approximately $100 \mathrm{~kb}$ distal to PGA and approximately $400 \mathrm{~kb}$ proximal to FEN 1 (Figure 1a). In addition, PCR amplification of a $62 \mathrm{bp}$ fragment derived from the 5 '-end of the gene (corresponding to nucleotides $+441-+502$ with $A=+1$ of the ATG start codon) in PAC clone dJ 71C 4, but not in dJ 398K 24 or dJ 506K 16 (Figure 1b), defines the orientation of transcription of the DD B 1 gene from telomere to centromere (Figure 1a).

A

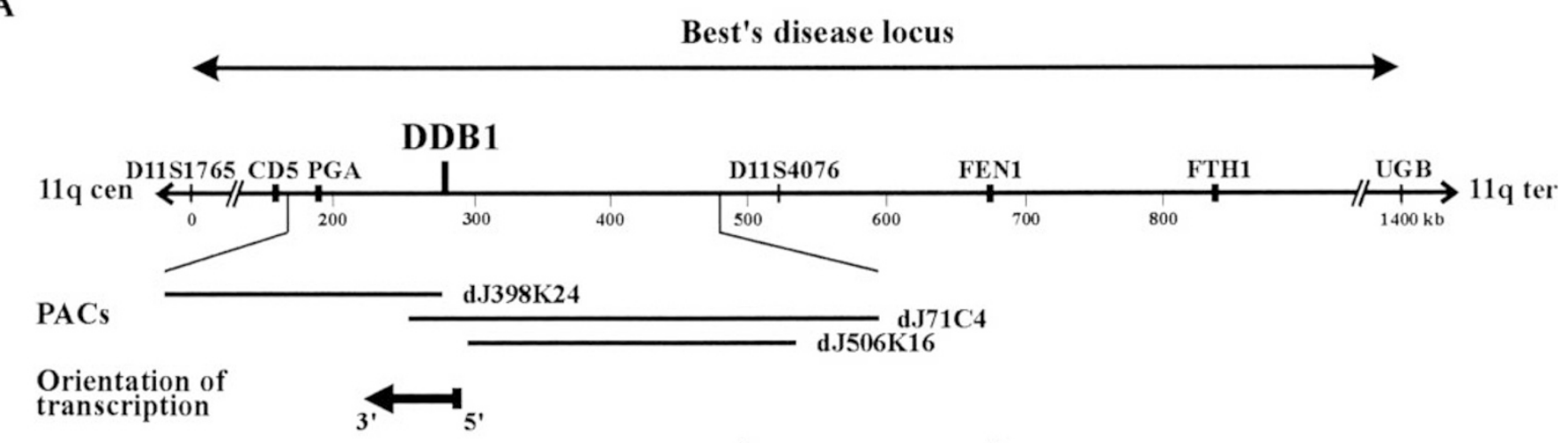

B

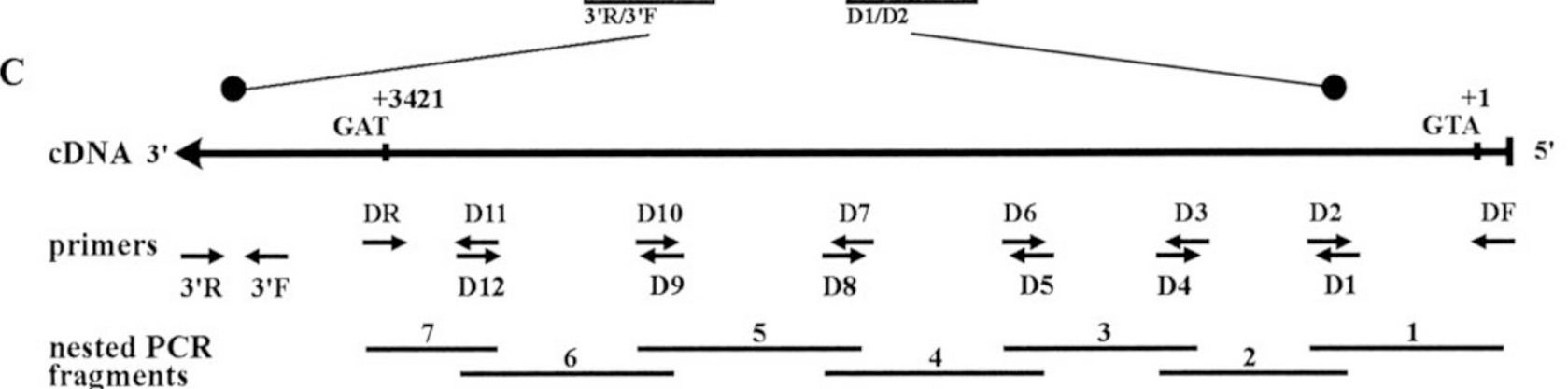

Figure 1 A Schematic representation of the B est's disease locus on chromosome 11q12-q13.1 showing the localisation of known genes within the critical interval. O verlapping PAC clones dJ 398K 24, dL 71C 4 and dJ 506K 16 are part of a high-coverage PAC contig described elsewhere. ${ }^{8}$. B PCR mapping of the $5^{\prime}$ - and $3^{\prime}-U T R$ of the DDB 1 gene using primer pairs D $1 / D 2$ and $3^{\prime} R / 3^{\prime} F$, respectively. The results demonstrate the orientation of transcription to be from the telomere to the centromere (arrow). C $L$ ocation of oligonucleotide primers within the full length DDB 1 CD NA used in the present study. Nested PCR fragments were analysed utilising SSCA and direct sequencing. The location of primers used for establishing the orientation of transcription within the established PAC contig is indicated by filled circles. 


\section{Expression Analysis of DDB1}

Northern blot analysis of DDB1 identifies a $4.4 \mathrm{~kb}$ transcript in total RNA of RPE, lung, cerebellum, retina and the RPE cell line, ARPE-19 (Figure2). A comparison of the signal intensities relative to the $\beta$-actin control hybridisation reveals an abundance of the DDB 1 transcript in retinal tissue (Figure 2).

\section{Genetic Analysis}

To investigate linkage in Best's disease families $R, H$ and $W$ to chromosome 11q12-q13.1, we determined the genotypes of all family members at polymorphic loci D 11S1765, D 11S4076 and U GB (Figure 1a). In family $R$, the four affected individuals in three generations share haplotype 6-1-5 (D 11S1765-D 11S4076-U GB). Similarly, in family $\mathrm{H}$, the five patients in three generations all carry a 6-1-5 haplotype. Finally, in family $W$, the five patients in three generations share a 7-2-5 haplotype (data not shown). Together, these analyses suggest a chromosome 11q12-q13.1 location of the disease gene in these three families.

\section{Mutational Analysis of DDB1}

In order to assess the DDB 1 gene for mutations in the six B est's disease patients we used reverse transcriptase (RT)-PCR to amplify seven overlapping CDNA fragments together encompassing the entire coding region of the D D B 1 gene (Figure 1c). Subsequently, restriction enzyme-digested PCR fragments were subjected to SSCA using two conditions to increase sensitivity. No abnormal migration of single stranded CDNA $s$ were observed for any of the six probands in all seven CDNA fragments analysed. In addition, approximately $60 \%$ of the coding region of DDB 1 was directly sequenced in four of the six Best's disease patients. Comparison to the published CDNA sequence of DDB1 (GenBank A cc. No. U 18299) has not revealed any sequence alterations.
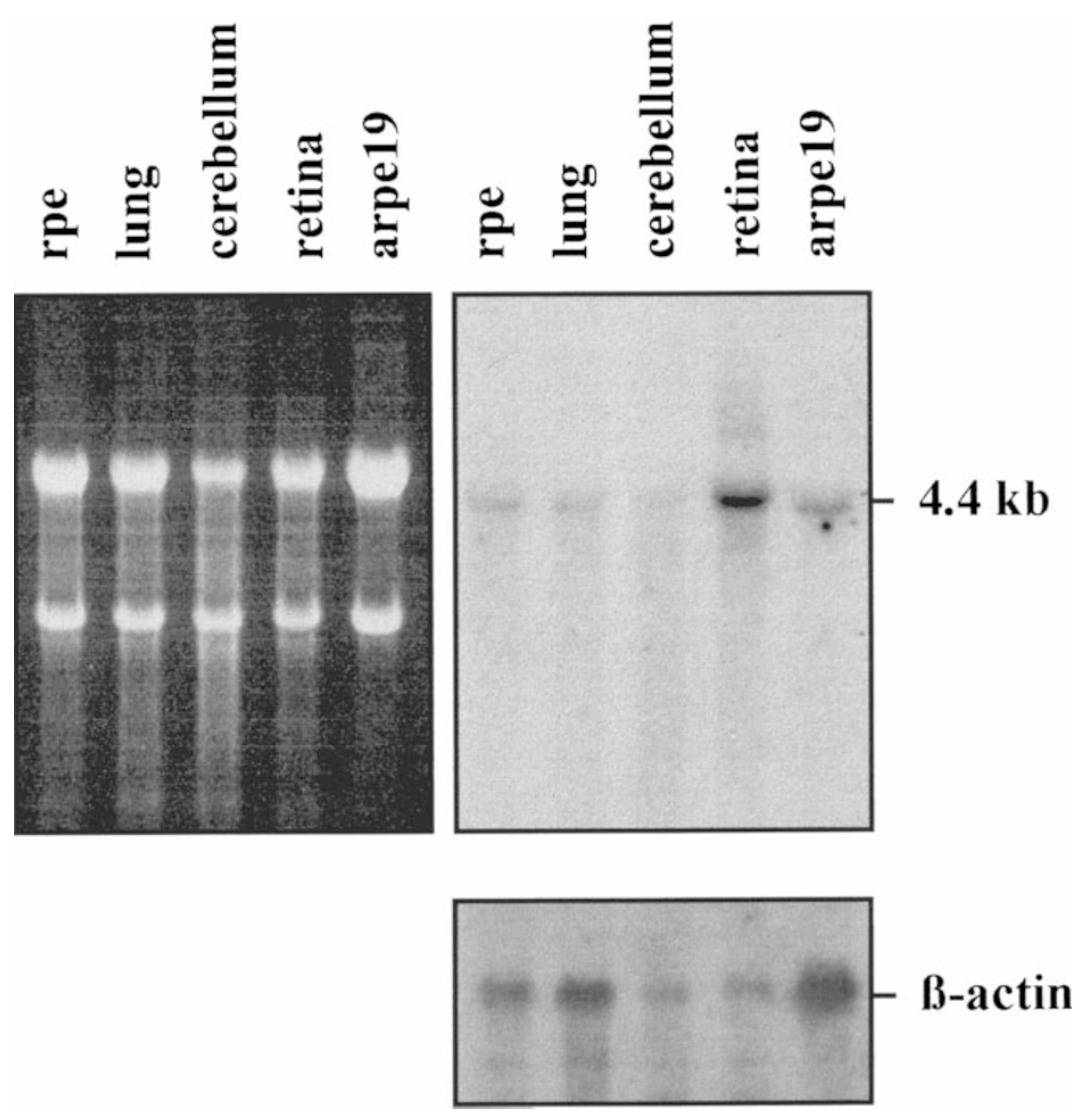

Figure 2 Northern blot analysis of DDB 1 in total RNA from retinal pigment epithelium (rpe) lung, cerebellum, retina and cell line RNA of retinal pigment epithelium (arpe19). L oading and R NA integrity was determined by ethidium-bromide stained gel analysis (left) and control hybridisation with a human $\beta$-actin probe (below). A lthough the $4.4 \mathrm{~kb}$ transcript is present in all tissues tested a preferential expression in retina is apparent. 


\section{Discussion}

A Ithough the autosomal dominant Best's vitelliform macular dystrophy was already described in $1905,{ }^{1}$ the primary cause leading to the disease phenotype still remains elusive. The availability of an increasing number of genes and knowledge of their probable functions makes it now feasible to assess attractive candidates that map within the chromosomal region known to harbour the disease locus. In this study, we have performed a detailed localisation of the DDB1 gene within the critical Best's disease region. The $127 \mathrm{kDa} \mathrm{DDB} 1$ subunit together with the $48 \mathrm{kDa}$ $D D B 2$ subunit form a functional heterodimer, DDB, that is presumed to participate in U V-damaged DNA recognition and nucleotide excision repair. ${ }^{9} \mathrm{O}$ ur northern blot analysis has shown that the $4.4 \mathrm{~kb}$ DDB 1 transcript is expressed in all tissues examined consistent with previous findings that have demonstrated an ubiquitious expression in many tissues including pancreas, kidney, skeletal muscle, liver, lung, heart, placenta and brain. ${ }^{13}$ In addition, our analysis has revealed a striking abundance of the DDB1 transcript in the human retina suggesting that the corresponding protein may play an important role in this tissue.

A side from its proposed role in UV-damaged DNA repair, DDB is thought to exert alternate but as yet unknown functions. ${ }^{9}$ This may particularly be true in tissues such as the retina that normally are protected from the most D NA -damaging UV light, UV-B, by the filtering capacity of cornea and lens. ${ }^{14}$ In light of our Northern blot results the retina seems to be an excellent tissue in which DDB functions should be further analysed.

To assess the $3420 \mathrm{bp}$ of coding sequence of the DDB 1 transcript in Best's disease we have developed an RT-PCR assay. However, a combination of SSCA and direct sequencing has not revealed any sequence alterations in our six patients. N evertheless, it should be pointed out that some minor types of mutations may have been missed using our assay, eg deletion of a complete allele or mutations in the promotor region of the gene. Also, it is commonly believed that SSCA detects on average approximately $80 \%$ of sequence variations. To further exclude the possibility of locus heterogeneity in Best's disease, we have performed linkage analyses in three out of six families where D NA samples of several affected and unaffected members were available. In each case, our results are consistent with a location of the disease locus to chromosome 11q12-q13.1. This is in excellent agreement with a series of earlier reports that demonstrate genetic homogeneity in Best's disease. ${ }^{2,3,7,11}$ Together, our results make it unlikely that $D D B 1$ is a major primary cause in the pathogenesis of Best's disease.

\section{Acknowledgements}

The authors wish to thank the families for their kind cooperation and Drs U Langenbeck (Institut für Humangenetik, Frankfurt) and $H$ Schilling (U niversitäts-A ugenklinik, Essen) for providing DNA samples from the Best's disease families. This work was supported by a grant from the D eutsche Forschungsgemeinschaft (DFG) (We1259/2-3).

\section{References}

1 Best F : Ü ber eine herediäre $M$ aculaffection: B eiträge zur Vererbungslehre. Z A ugenheilkd 1905; 13: 199-212.

2 Stone E, Nichols BE, Streb LM, K imura AE, Sheffield VC: $G$ enetic linkage of vitelliform macular degeneration (Best's disease) to chromosome 11q13. N at G enet 1992; 1: 246-250.

3 Forsman K, Graff C, Nordstrom S et al: The gene for Best's macular dystrophy is located at $11 q 13$ in a Swedish family. Clin G enet 1992; 42: 156-159.

4 Weingeist TA, Kobrin J L, Watzke R C: H istopathology of Best's macular dystrophy. Arch Ophthalmol 1982; 100: 1108-1114.

5 O'Gorman S, Flaherty WA, Fishman GA, Berson EA : $\mathrm{H}$ istopathologic findings in Best's vitelliform macular dystrophy. A rch O phthalmol 1988; 106: 1261-1268.

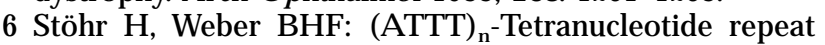
polymorphism in the 5 '-flanking region of the $U G B$ gene. $\mathrm{H}$ um M ol G enet 1994; 3: 2086.

7 Wadelius C, G raff C, Forsman K, E riksson A, Sandgren O, Weissenbach J, Holmgren $G$ : G enetic and physical mapping of the gene for B est's macular dystrophy. A m J H um G enet 1996; 59: 1384.

8 Cooper PR, Nowak NJ, Higgins MJ, et al: A sequenceready high-resolution physical map of the Best's macular dystrophy gene region in 11q12-q13. G enomics 1997; 41: 185-192.

9 Dualan R, Brody T, Keeney S, Nichols A F, A dmon A, $L$ inn S: Chromosomal localization and CDNA cloning of the genes (DDB1 and DDB2) for the p127 and p48 subunits of a human damage-specific DNA binding protein. G enomics 1995; 29: 62-69.

10 D unn K C, A otaki-K een A E , Putkey FR, H jelmeland L M : A RPE-19, a human retinal pigment epithelial cell line with differentiated properties. Exp E ye Res 1996; 62: 155- 169.

11 Stöhr H, Weber BHF:A recombination event excludes the ROM 1 locus from the Best's vitelliform macular dystrophy region. $\mathrm{H}$ um $\mathrm{G}$ enet 1995; 95: 219-222.

12 D ib C, Faure S, Fizames C et al: A comprehensive genetic map of the human genome based on 5264 microsatellites. Nature 1996; 380: 152-154. 
13 Takao M, A bramic M, Moos Jr M et al: A $127 \mathrm{kDa}$ component of a UV-damaged DNA-binding complex, which is defective in some xeroderma pigmentosum group $\mathrm{E}$ patients, is homologous to a slime mold protein. Nucl A cids Res 1993; 21: 4111-4118.
14 Dillon J : The photophysics and photobiology of the eye. J Photochem Photobiol B 1991; 10: 23-40. 